\title{
Effect of polypropylene fibers on high strength mortar subjected to elevated temperature
}

\author{
Muhammad Ridwan ${ }^{1}$, Hu Liang Jun ${ }^{2}$ and Isamu Yoshitake ${ }^{2}$ \\ ${ }^{1}$ Department of Civil Engineering, Institute Technology of Padang, Jalan Gajah Mada Kandis Nanggalo, Padang, 2500 Indonesia \\ ${ }^{2}$ Department of Civil and Environmental Engineering, Yamaguchi University, 2-16-1 Tokiwadai, Ube, Yamaguchi 755-8611, Japan
}

\begin{abstract}
This study focuses on the thermo-mechanical properties of mortar in the retrofitting cover of additional reinforcement for existing concrete structures. In addition, the residual mechanical properties of high strength mortar incorporating polypropylene fibers subjected to the effect of fiber length and the elevated temperature were investigated. Several experiments were conducted to determine the optimum mixture proportions of high strength mortar incorporating polypropylene fibers which had a slump-flow of $25-30 \mathrm{~cm}$, compressive strength of $50 \mathrm{MPa}$ or higher, and flexural strength of 4-8 MPa. Subsequently, an experiment was conducted by using high-strength mortar-blended polypropylene fibers with a length of $2 \mathrm{~cm}$, and the ratio of fiber length to the diameter of cylinder mortar-specimens was 0.4 . The experimental parameters were the weight volume of fibers $(0 \%, 0.5 \%, 1 \%$, and $2 \%)$ and the heating temperature $\left(100,200\right.$ and $\left.300{ }^{\circ} \mathrm{C}\right)$. The effect of the mixing parameters, including polypropylene length on compressive strength, slump-flow and the flexural strength of mortar were discussed. It is evident that fiber in the mortar cover influenced the initial and residual mechanical properties, such as elasticity, compressive strength, and Poisson's ratio, of the mortar.
\end{abstract}

\section{Introduction}

Indonesia is in a seismic area and frequently suffers earthquakes and fires. It can learn a lesson in Indonesia that the brick walls are always crashed by earthquakes $[1,2,3]$. Many efforts have been made to mitigate the damage and retrofitting is one of the approaches for improving structural safety after earthquakes. Retrofitting on buildings is often applied to the surface of the structural element. Usually, the replacement material as a filler in retrofitting is the high strength mortar. Fiber is often mixed in the mortar to achieve high strength of mortar, and polypropylene (PP) fiber is commonly used as additional material.

Polypropylene (PP), which has an extended size, can provide a better sticking effect, so the longer fiber will offer greater strength to the mortar. But sometimes the fiber is trapped in a narrow area, such as a cover of masonry structure and other small spaces in the retrofitting.

The brick wall (masonry) was widely used throughout Indonesia. Public houses and high-rise buildings are still using the brick wall as a partition between the rooms.

Fires occasionally occur in a building. The wall suffers an extensive and lasting exposure to high temperatures. Mortar consumption in a masonry wall could reach $40 \%$ of the wall per square meter [2]. Thus, the functions of fiber, as a binder of brick mortar, should be ensured even in a fire disaster. The utilization of fiber to strengthen the function of mortar and improve the service life of mortar has been developed in much research, especially the application of polypropylene as reinforcement.

Ezziane et al. had investigated the high-temperature behavior of fibers reinforced mortar when heating up to $500{ }^{\circ} \mathrm{C}$. The increase of the temperature, the strength gain due to fibers inclusion reduced. In the case of beyond $500{ }^{\circ} \mathrm{C}$, the bending strength of fiber-reinforced cementitious material is lower than that of those without fibers [4]. In another research, a test was conducted on three different fibers for mortar. The addition of fibers ensured an excellent ductility of mortar at temperatures from 400 to $700^{\circ} \mathrm{C}$. Khadra Bendjilati et al. conducted an experimental investigation on the physical and mechanical performance of mortar reinforced by fibers. In this experimental investigation, the mortar specimens were stored in three different environments for 91 days, including hot-dry, laboratory environment, and cold environment [5].

Researches on the performance of reinforced concrete in high temperatures are regularly conducted. The significant contribution of fiber to the resistance of reinforced concrete spalling occurs at temperatures up to $200{ }^{\circ} \mathrm{C}$, especially at $170{ }^{\circ} \mathrm{C}$. At $200{ }^{\circ} \mathrm{C}$ the grains will melt slowly, but many researchers were performed at temperatures above $200{ }^{\circ} \mathrm{C}$ [6].

Noumowe carried out a study on the use of fiber with limestone as fine aggregates under high temperatures [7]. He investigated the behavior of masonry and

\footnotetext{
* Corresponding author: mhd.rid.wan.itp@gmail.com
} 
simulated the peak shear stress of masonry mortar, mainly on joint under compression [8]. Modeling of masonry-infilled RC frames subjected to seismic load had been proposed by Rahman [9]. Stavridis retrofitted frames with ECC overlays [10]. Kumar proposed an analytical approach for failure modeling with plasticity [11].

Al-chaar carried out a FEM model to obtain the characteristics of masonry stiffness and conducted onsite testing to determine the mechanical properties and stress conditions on masonry walls. It aims to identify the value of material mechanical properties and minimizes the difference in calculation and measurement of displacements [12].

This paper investigates the behavior of long fibers blended in the mortar used in the narrow-thin areas of retrofitted structural elements suffering fires. In this study, the polypropylene fiber length was five times the maximum size of fine aggregate or larger than one-fifth of the diameter of cylindrical molds.

The present study aims to investigate the influence of the use of mortar mixed with polypropylene fiber and given the temperature of 100 to $300^{\circ} \mathrm{C}$ to changes in the thickness of the plaster as a connection between the interfaces of mortar layers. Besides, it also investigates the effect of polypropylene fibers length on high strength mortar subjected to elevated temperature.

\section{Material and test procedure}

\subsection{Material}

The use of limestone as fine aggregate and limestone powder as an additional comment [8] is also in use in this study, to consider the economic factors chosen PP fibers as reinforcement of mortar. It is done to look at the phenomenon that occurs when the PP undergoes melting. The modeling applied here is using a fiber size exceeding $1 / 5$ of the diameter of a cylindrical mortar mold. The material used in this study shown in Table 1 .

\subsection{Procedure}

Seventeen trials have been conducted to obtain the desired results by trial and error method. The first step was setting in Table 3 .

The changing weather conditions can make fineaggregate water content change, so different mixtures have been carried out to check the fine-aggregate moisture content. The procedure of mixing are limestone, cement, and limestone-powder mixture for one minute and then enter the water and superplasticizer, mixing for two minutes, Insert fiber and mixing for one minute, sample allowed to stand for three minutes. Before it is put into the cylinder mold has to be checked workability with a slump flow test, the curing carried out for 28 days in water at a temperature of 24 degrees Celsius.
Table 1. Materials for test

\begin{tabular}{|c|c|c|}
\hline Cement(C) & $\begin{array}{l}\text { ordinary } \\
\text { Portland } \\
\text { cement }\end{array}$ & see Table 2. \\
\hline $\begin{array}{l}\text { Limestone } \\
\text { powder(LP) }\end{array}$ & $\begin{array}{l}\text { ground } \\
\text { limestone } \\
\text { powder }\end{array}$ & see Table 2. \\
\hline $\begin{array}{l}\text { Fine agregate } \\
\text { ASTM C33-90 }\end{array}$ & $\begin{array}{l}\text { crused } \\
\text { limestone sand }\end{array}$ & $\begin{array}{l}\text { Density }=2.62 \\
\mathrm{~g} / \mathrm{cm}^{3} \\
\mathrm{FM}=2.75 \\
\text { Size } 5-\mathrm{mm}\end{array}$ \\
\hline $\begin{array}{l}\text { Polypropylene } \\
\text { (PP) } \\
\text { ASTM C-1116 }\end{array}$ & $\begin{array}{l}\text { Virgin } \\
\text { Homopolymer } \\
\text { tensile strength } \\
\text { length } \\
\text { melting point }\end{array}$ & $\begin{array}{l}\text { Fibrillated Twisted- } \\
\text { Bundle Fiber } \\
0.91 \text { grams } / \mathrm{cm}^{3} \\
570-660 \mathrm{MPa} \\
19 \mathrm{~mm} \\
170^{\circ} \mathrm{C}\end{array}$ \\
\hline Superplasticizer & $\begin{array}{l}\text { SF500H AE, } \\
120 \mathrm{~A}\end{array}$ & \\
\hline
\end{tabular}

Table 2. Physical and chemical compositions of cement

\begin{tabular}{|c|c|c|}
\hline & Cement (C) & $\begin{array}{l}\text { Limestone } \\
\text { powder (LP) }\end{array}$ \\
\hline $\begin{array}{l}\text { Density } \\
\text { Baine fineness } \\
\text { Setting time } \\
\text { Comp.strength at } \\
3 \text { days } \\
\quad \text { at } 7 \text { days } \\
\quad \text { at } 28 \text { days }\end{array}$ & $\begin{array}{l}3.15 \mathrm{~g} / \mathrm{cm}^{3} \\
3185 \mathrm{~cm}^{2} / \mathrm{g} \\
2 \mathrm{~h}-3 \mathrm{~h} \\
\\
28.6 \mathrm{MPa} \\
46.1 \mathrm{MPa} \\
62.5 \mathrm{MPa}\end{array}$ & $\begin{array}{l}2.7 \mathrm{~g} / \mathrm{cm}^{3} \\
5000 \mathrm{~cm}^{2} / \mathrm{g} \\
\text { N/A } \\
\text { N/A } \\
\text { N/A } \\
\text { N/A }\end{array}$ \\
\hline $\begin{array}{l}\text { Chemical } \\
\text { composition } \\
\mathrm{CaO} \\
\mathrm{SiO}_{2} \\
\mathrm{Al}_{2} \mathrm{O}_{3} \\
\mathrm{Fe}_{2} \mathrm{O}_{3} \\
\mathrm{MgO} \\
\mathrm{SO}_{3} \\
\mathrm{Cl}^{-} \\
\text {Loss of ignition }\end{array}$ & $\begin{array}{l}64.3 \% \\
20.4 \% \\
5.7 \% \\
2.9 \% \\
1.08 \% \\
1.89 \% \\
0.017 \% \\
2.25 \%\end{array}$ & $\begin{array}{l}55.62 \% \\
0.09 \% \\
0.010 \% \\
0.013 \% \\
0.35 \% \\
0.00 \% \\
0.00 \% \\
43.8 \%\end{array}$ \\
\hline
\end{tabular}

Table 3. The boundary condition for attempt repeatedly

\begin{tabular}{|c|c|c|}
\hline \multicolumn{2}{|c|}{ W/C } & $30 \%$ \\
\hline \multicolumn{2}{|c|}{ Diameter Slump Flow Test $(\mathrm{mm})$} & $250-300$ \\
\hline Flexural & $\mathrm{MPa}$ & $\geq 8$ \\
\hline $\begin{array}{c}\text { Compression Strength } \\
f^{\prime} m\end{array}$ & $\mathrm{MPa}$ & $40-80$ \\
\hline Cementation Material & $\mathrm{Kg} / \mathrm{m} 3$ & $\geq 200$ \\
\hline Cement Content & $\mathrm{Kg} / \mathrm{m} 3$ & $\leq 300$ \\
\hline Slump Flow & $\mathrm{cm}$ & $\geq 20$ \\
\hline
\end{tabular}

\subsection{Mixture proportion}

Proportion of the first mixing result is the initial value of the achievement. A slump flow test is an indicator of each experiment. From the test results shown in the visualization occurs segregation and even become the basis for further changes in mixture proportions. A mix that expected when it reaches a diameter of $25 \mathrm{~cm}$.

The compressive strength test and flexural tests did after soaking-treatment 28 days at a temperature of 
$23{ }^{\circ} \mathrm{C}$. The mix proportion to be changed for the next steps if the results do not meet the targets. The last result of trial and error of mixture proportion is shown in Table 4.

Table 4. Mixture proportion

\begin{tabular}{|c|c|}
\hline $\mathrm{W} / \mathrm{C}$ & $30 \%$ \\
\hline $\mathrm{W}$ & $231 \mathrm{~kg} / \mathrm{m}^{3}$ \\
\hline $\mathrm{C}$ & $500 \mathrm{~kg} / \mathrm{m}^{3}$ \\
\hline $\mathrm{LS}$ & $1282 \mathrm{~kg} / \mathrm{m}^{3}$ \\
\hline $\mathrm{LSP}$ & $271 \mathrm{~kg} / \mathrm{m}^{3}$ \\
\hline $\mathrm{SP}$ & $5 \mathrm{~kg} / \mathrm{m}^{3}$ \\
\hline
\end{tabular}

\subsection{Heat setting test}

The last result of mix proportion was used to the process of making specimens to the experiment of heating. 48 cylinder diameter $5 \mathrm{~cm}$ specimen has in being prepared and some combination of temperature. It is shown in Table 5.

Table 5. Number of specimens

\begin{tabular}{|c|c|c|c|c|}
\hline \multirow{2}{*}{ Temperature ${ }^{\circ} \mathrm{C}$} & \multicolumn{5}{|c|}{ PP Fiber (\%) } \\
\cline { 2 - 5 } & 0 & 0.5 & 1 & 2 \\
\hline Room Temperature & 3 & 3 & 3 & 3 \\
\hline 100 & 3 & 3 & 3 & 3 \\
\hline 200 & 3 & 3 & 3 & 3 \\
\hline 300 & 3 & 3 & 3 & 3 \\
\hline
\end{tabular}

This study used Electrical heating machine furnace type with NHK-120H-2 $800 \mathrm{~W}$ model and have a maximum temperature around $1000{ }^{\circ} \mathrm{C}$. The warm-up specimens following in Table 5.

Let stand the specimens at room temperature to reduce the levels of surface water before warming specimens. It was done to avoid blasting. Before warming a specimen at first, let stand at room temperature to reduce the levels of surface water. It was done to avoid blasting samples. The heating rates were $5^{\circ} \mathrm{C} / \mathrm{min}$ before reaching the target temperature. After reaching a temperature of the heat. The warming plan carried out for 60 minutes and after it is done with cooling by the room temperature before tested. The temperature, time curve is given in Figure 1.

After exposed to elevated temperature, the unit weight determined for each specimen according to ASTM C642-06 average values of the density of the specimens shown in Table 6.

Checking of density is done start after curing, before and after the warming, it is doing that would likely happen to evaporate in specimens during the waiting time.

After exposed to elevated temperature, the unit weight determined for each specimen according to ASTM C642-06 average values of the density of the specimens shown in Table 6 .

Checking of density is done start after curing, before and after the warming, it is doing that would likely happen to evaporate in specimens during the waiting time.

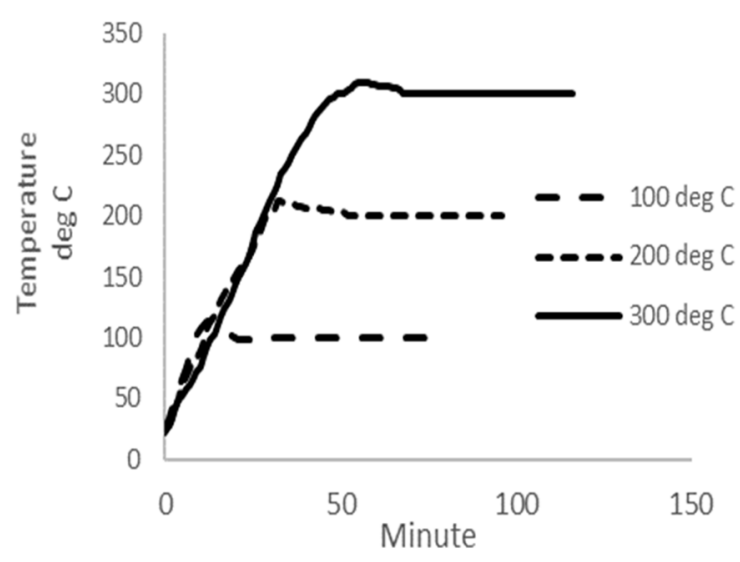

Fig. 1. Temperature-time curves.

\section{Test results and discussion}

Compressive strength of mortar tested using the universal compression machine. Some test has done to all specimens to obtain the compressive strength $f_{c-m}^{\prime}$, the elastic modulus of mortar $E_{m}$, Poisson ratio $\mu$ and density $\gamma$. The elastic modulus of mortar evaluated according to;

$$
E_{1}=\frac{S_{1}-S_{2}}{\varepsilon_{1}-50 \times 10^{-6}}
$$

Each specimen recorded by four strain gauges to the horizontal and vertical directions. Figure 2a, 2b, $2 c$. and $2 \mathrm{~d}$ show the corresponding stress-strain diagrams for $0 \%$ PP to $2 \% \mathrm{PP}$.

Drysdale et al. have recommended that Modulus of Elasticity of masonry may take as [16]:

$$
E_{m}=k f_{m}
$$

Where $f_{m}$ is the compressive strength of masonry prism in MPa. and $k$ values between $500{ }^{\circ} \mathrm{C}$ to $600{ }^{\circ} \mathrm{C}$. When assuming a modulus of elasticity equal to the elastic modulus of mortar masonry, so $k$ value in Table 6 is nearing when compared with the analysis of the material used in this study.

Compared to the Gautan Mondal study [13], The $\mathrm{k}$ average in this study ranged $f_{\mathrm{m}}$ is 480.19 for $0 \% \mathrm{PP}$, 496.6 for $0.5 \%$, for the $1 \% \mathrm{PP}$ is 490.19 and 541.48 for the $2 \%$ PP. This data applies at all temperatures. However, all the value is below 550 .

The average decline in every increase in temperature and an increase in the percentage of fibers. Every rise in temperature of $100{ }^{\circ} \mathrm{C}$ degradation of Elasticity is $7.87 \%$, for $0.5 \% \mathrm{PP}, 9.61 \%$ for $1 \% \mathrm{PP}, 7.78 \%$ and $2 \%$ PP around $10.3 \%$. 
Table 6. Test Results

\begin{tabular}{|c|c|c|c|c|c|c|}
\hline $\begin{array}{c}\text { PP fiber } \\
\%\end{array}$ & $\begin{array}{c}\text { Temp. } \\
{ }^{\circ} \mathrm{C}\end{array}$ & $\begin{array}{c}\mathrm{E} \\
(\mathrm{MPa})\end{array}$ & $\begin{array}{c}f_{\text {'m }} \\
(\mathrm{MPa})\end{array}$ & $\begin{array}{c}\text { Poisson's } \\
\text { ratio }\end{array}$ & $\begin{array}{c}\text { Density } \\
\mathrm{t} / \mathrm{m}^{3}\end{array}$ & $\mathrm{k}$ \\
\hline 0 & 24 & 41607 & 84.97 & 0.27 & 2.33 & 490 \\
\hline & 100 & 37978 & 79.60 & 0.25 & 2.32 & 477 \\
\hline & 200 & 34995 & 69.94 & 0.24 & 2.29 & 500 \\
\hline & 300 & 31782 & 70.06 & 0.22 & 2.19 & 540 \\
\hline & 24 & 41627 & 81.60 & 0.26 & 2.33 & 510 \\
\hline & 100 & 36044 & 72.63 & 0.25 & 2.34 & 496 \\
\hline & 200 & 35339 & 67.47 & 0.24 & 2.35 & 524 \\
\hline & 300 & 29630 & 64.93 & 0.23 & 2.58 & 456 \\
\hline & 24 & 35151 & 68.30 & 0.25 & 2.34 & 515 \\
\hline & 100 & 31504 & 66.18 & 0.24 & 2.35 & 476 \\
\hline & 200 & 27357 & 57.20 & 0.24 & 2.38 & 478 \\
\hline & 300 & 26951 & 54.80 & 0.25 & 2.38 & 492 \\
\hline & 24 & 38238 & 64.89 & 0.26 & 2.30 & 589 \\
\hline & 100 & 32089 & 62.39 & 0.26 & 2.30 & 514 \\
\hline & 200 & 28438 & 55.06 & 0.23 & 2.34 & 546 \\
\hline & 300 & 26048 & 47.72 & 0.24 & 2.35 & 546 \\
\hline
\end{tabular}

The compression strength of the above results was also a decline in the temperature changes is increasing the heating temperature get the lower compressive strength of specimens. For $0 \%$ of PP consumption occurs every $100{ }^{\circ} \mathrm{C} 5.85 \%$ and $6.81 \%$ for $0.5 \% ; 6: 59$ to $1 \%$ and $2 \%, 8.82 \%$ degradation.

Table 7. Reduction of density

\begin{tabular}{|c|c|c|c|}
\hline \multirow{2}{*}{$\mathrm{PP} \%$} & \multicolumn{3}{|c|}{ Temperature $^{\circ} \mathrm{C}$} \\
\cline { 2 - 4 } & 300 & 200 & 100 \\
\hline & $\%$ & $\%$ & $\%$ \\
\hline 0.5 & 7.63 & 4.12 & 1.87 \\
\hline 1 & 7.64 & 4.80 & 2.21 \\
\hline 2 & 7.99 & 4.39 & 2.33 \\
\hline
\end{tabular}

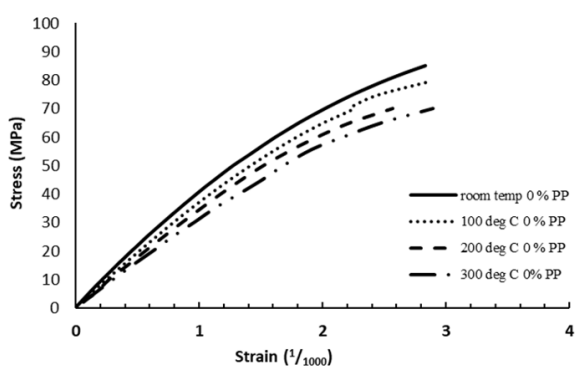

Fig. 2a. Stress-strain of $0.0 \% \mathrm{PP}$

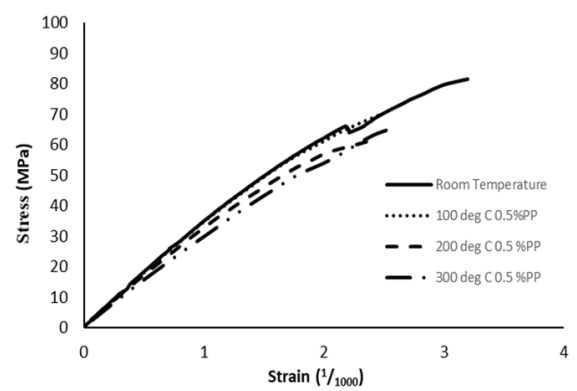

Fig. 2b. Stress-strain of $0.5 \% \mathrm{PP}$

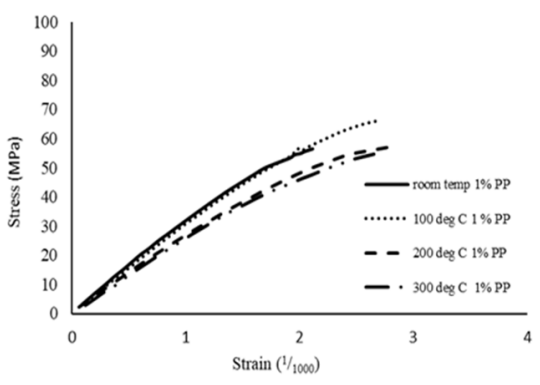

Fig. 2c. Stress-strain of $1 \%$ PP

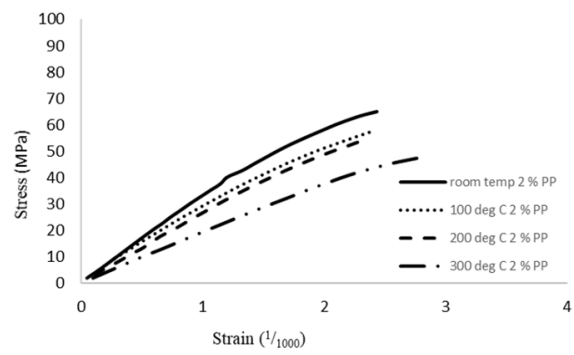

Fig. 2d. Stress-Strain of $2 \%$ PP

When viewed from each of the percentage change in the rate of degradation are relatively similar. As with the Poisson ratio, every increase in temperature Poisson Ratio decreased. The Poisson ratio was ranging from $6: 17 \%$ to $2: 56 \%$, but for $1 \%$ PP. It is similar from 0.24 until 0.25 . The highest value Poisson Ratio is when the room temperature test is 0.27 , and the lowest was 2.23 at a temperature of $200{ }^{\circ} \mathrm{C}$ and $2 \% \mathrm{PP}$. Average reduction 0.01 every change in temperature of $100{ }^{\circ} \mathrm{C}$ every percentage the used of PP. The changes in density shown in Table 7.

Percentage of decrease in density for each percentage the using of PP base on the increase the temperature, the percentage of PP risen by $0.5 \% \mathrm{PP}$ from $1.87 \%$ to $7.63 \%$, for the $1 \%$ PP from $2.21 \%$ to $7.64 \%$ and $2 \%$ PP from $2.33 \%$ to $7.99 \%$. 
To a temperature of $100{ }^{\circ} \mathrm{C}$ ranged from $1.87 \%$ to $2.33 \%$, for $200{ }^{0} \mathrm{C}$ temperature range from $4.12 \%$ to $4.8 \%$ and a temperature of $300{ }^{\circ} \mathrm{C}$ for between $7.63 \%$ to $7.99 \%$. The addition of PP is the same relative reduction the density at different temperature levels.

\section{References}

1. M. Ridwan, I. Yoshitake, A. Y. Nassif, Adv. Civ. Eng., doi:10.1155/2017/6456070 (2017)

2. M. Ridwan, I. Yoshitake, A. Y. Nassif, Constr. Build. Mater. 152, doi:10.1016/j.conbuildmat.2017.06.138 (2017)

3. M. Ridwan, R. Kurniawan, doi:10.1051/matecconf/201821501034

4. M. Ezziane, T. Kadri, L. Molez, R. Jauberthie, A. Belhacen, Fire Saf. J. 71 324-331 (2015)

5. M. S. Cülfik, T. Özturan, Cem. Concr. Res. 32, 809-816 (2002)

6. K. Bendjillali, M. Chemrouk, M. S. Goual, B. Boulekbache, Eur. J. Environ. Civ. Eng. 17 687699 (2013)
7. A. Noumowe, Cem. Concr. Res. 35 2192-2198 (2005)

8. I. Yoshitake, H. Wong, T. Ishida, A. Y. Nassif, Constr. Build. Mater. 71, 216-225 (2014)

9. A. Rahman, T. Ueda, J. Mater. Civ. Eng. 26, 04014061 (2013)

10. A. Stavridis, (2007).

11. N. Kumar, R. Amirtham, M. Pandey, Eng. Struct. 80 40-52 (2014)

12. G. K. Al-chaar, A. Mehrabi, Director 69 (2008).

13. I. Haris, Z. Hortobágyi, Period. Polytech. Civ. Eng. 56 25-34 (2012)

14. T. Turgay, M. C. Durmus, B. Binici, G. Ozcebe, J. Struct. Eng. 140, 06014003 (2014)

15. G. Mondal, S. K. Jain, Earthq. Spectra. 24 701-723 (2008)

16. G.R. Drysdale, Hamid.A.A, and Baker, R. L., Prentice Hall., Upper Saddle River (1993) 